\title{
Effect of processing methods and storage time on physical characteristics of palm oil
}

\author{
Nwakodo, C. S. ${ }^{1}$, Udensi, E. A. ${ }^{2}$ and Chukwu, M. N. ${ }^{1^{\star}}$ \\ ${ }^{1}$ Department of Food Technology, Abia State Polytechnic, Aba, Abia State, Nigeria. \\ ${ }^{2}$ Department of Food Science and Technology, Abia State Unniversity, Uturu, Abia State, Nigeria. \\ *Corresponding author. Email: mchukwu61@gmail.com. Tel: +2348184516106.
}

Copyright (C) 2018 Nwakodo et al. This article remains permanently open access under the terms of the Creative Commons Attribution License 4.0, which permits unrestricted use, distribution, and reproduction in any medium, provided the original work is properly cited.

Received 6th November, 2018; Accepted 8th December, 2018

\begin{abstract}
The effect of processing methods and the storage time on the physical characteristics of palm oil was determined. Samples of palm oil were produced using four processing methods (Hot Extraction; Cold Extraction; Hot Extraction with Red Sand and Mechanized Extraction), packaged in plastic containers and stored at ambient temperature for 0 to 3 month(s). There was significant increase in the following physical characteristics of the palm oil samples due to the storage time: cloud point $\left(21.13\right.$ to $\left.24.13^{\circ} \mathrm{C}\right)$, melting point $\left(39.54\right.$ to $\left.41.88^{\circ} \mathrm{C}\right)$ and moisture content $(0.068$ to $0.390 \%)$. However, significant decrease occurred in the following characteristics: smoke point $\left(195.30\right.$ to $\left.186.3^{\circ} \mathrm{C}\right)$, flash point $\left(252.37\right.$ to $\left.244.62^{\circ} \mathrm{C}\right)$, fire point $\left(314.87\right.$ to $\left.306.37^{\circ} \mathrm{C}\right)$ and refractive index $(1.45$ to 1.37$)$. The effects of the four processing methods on the physical characteristics of palm oil were determined. Processing methods had no significant variations in specific gravity $(0.902$ to 0.905$)$ and fire point $\left(309.62\right.$ to $\left.313.25^{\circ} \mathrm{C}\right)$ while significant variations occurred in cloud point $\left(22.38\right.$ to $\left.23.56^{\circ} \mathrm{C}\right)$, smoke point $\left(188.38\right.$ to $\left.195.50^{\circ} \mathrm{C}\right)$, melting point $\left(40.16\right.$ to $\left.41.63^{\circ} \mathrm{C}\right)$, flash point $\left(240.75\right.$ to $\left.268.50^{\circ} \mathrm{C}\right)$, moisture content (0.08 to $0.37 \%$ ) and refractive index (1.39 to 1.44). Mechanized extraction method of palm oil was observed as the best method because its palm oil had the least specific gravity $(0.902 \pm 0.006)$, least cloud point $(22.38$ $\pm 1.75^{\circ} \mathrm{C}$ ), highest smoke point $\left(195.50 \pm 1.41^{\circ} \mathrm{C}\right)$, least melting point $\left(40.16 \pm 1.03^{\circ} \mathrm{C}\right)$, highest flash point $\left(218.50 \pm 3.67^{\circ} \mathrm{C}\right)$, highest fire point $\left(313.25 \pm 2.96^{\circ} \mathrm{C}\right)$, least moisture content $(0.08 \pm 0.02 \%)$ and highest refractive index $(1.44 \pm 0.01)$. Similar study on the effect of processing methods and storage time on chemical properties of palm oil is recommendable.
\end{abstract}

Keywords: Cloud point, fire point, palm oil, processing method, smoke point, storage.

\section{INTRODUCTION}

Oil palm (Elaeis guineensis) is an indigenous tree to West Africa. Elaeis is a Greek word "elation" meaning oil and the specific name guineensis indicating its origin to the Guinea Coast (Umoh, 1998). The Oil Palm exists in wild, semi-wild and cultivated states in the three land areas of the equatorial tropics, in Africa, South-East Asia and in America. Palm oil is edible oil referred to by the FAO/WHO Codex Alimentarius as being derived from the fleshy mesocarp of the oil palm fruit and palm kernel oil is derived from the kernel of the fruit of the oil palm (FAO/WHO, 2013).

Palm oil is an important vegetable oil that is cultivated as a source of oil and has an increasing consumer interest in tropical West Africa. It is believed that low quality of palm oil is a result of methods of processing and storage. It is a known fact that quality of palm oil to a large extent determines its usefulness in both domestic and industrial applications (Enyoh et al., 2017b). Palm oil is the most commonly used vegetable oil in Nigeria; it is orange-red to brownish or yellowish-red in colour. The palm fruit, a tropical tree crop takes five to six months to mature from pollination and it is mainly grown for its industrial production of vegetable oil. It is cultivated over large uniform areas close to central oil mill to enable rapid industrial handling or processing after harvesting. After processing the palm fruit, oil is extracted from both the pulp of the fruit and the kernel (Agbaire, 2012; Enyoh et al., 2017a).

Palm oil (Elaeis guineensis) meets $80 \%$ of total edible oil needs and it is estimated that $30 \%$ of crude palm oil (CPO) 
production is provided by none industrial oil mills (Ohimain et al., 2012). The quality is associated with the method of processing. There are three types of oil palm processors, traditional (mostly manual), semi-mechanized and mechanized processors (Ngando-Ebongue et al., 2013). To a larger extent, smallholder/traditional processor dominate the sector accounting about $80 \%$ (Ohimain et al., 2012). Smallholder processors maintain low level of hygiene in the processing mills (Ngando-Ebongue et al., 2006; Okechalu et al., 2011). These have resulted to low quality of CPO. Authors have reported the physicochemical and microbiological properties of CPO processed traditionally to be of poor quality. The semimechanized processor share about $50 \%$ of smallholder characteristics (Izah and Ohimain, 2013, Enyoh et al., 2017a,b).

The various methods for palm oil processing have been compiled in a bulletin by Food and Agriculture Organization (FAO, 2002) of the United Nations. The compilation explains that batch processes is often employed by small-scale facilities, which process two or less tones of fresh fruit bunch per hour. The small scale factories make use of manual skilled labourers. On the other hand, large-scale plants process more than ten and often up to sixty tones of fresh fruit bunches per hour (Enyoh et al., 2017a). The level of oil extraction varies wildly, mainly due to the different methods. In Imo state, in the traditional/local channel most of the palm oil is produced by women using manual traditional method namely mortar and pestle. Oil extracted usually reaches only $25 \%$ of the available oil in the fruit (Enyoh et al., $2017 \mathrm{~b}$ ). The major processing activities irrespective of kind of processing that could affect the quality of CPO produced include bruises during transportation, fermentation prior to threshing, clarification and storage (Ohimain et al., 2013).

Structurally, each fruit has an outer skin. Beneath, it is a layer of fibrous pulp called the mesocarp, which is rich in palm oil and contains 50 to $55 \%$ oil. The seed or nut is inside the mesocarp. The nut consists of an outer hard black shell and an inner kernel which is rich in oil, called palm kernel oil. This is the second type of oil produced from the oil palm fruit. The colour is usually pale yellow (the oil is more liquid than palm oil hence it is composed of mainly unsaturated fatty acids primarily lauric acid) while palm oil is orange to reddish of the fruit mainly after due processing and extraction (Ihekoronye and Ngoddy, 1985).

Fats and oils represent the highest source of energy per unit weight that man can consume. Apart from being a source of reserved energy, fats deposit insulates the body against loss of heat and protects vital organs against mechanical injury (Barku-Atsu et al., 2012). They are important food source for man, and are also extensively used for nutritional, cosmetic, drug dispersant in therapeutics and industrial purposes and are used for supplying essential fatty acids such as linoleic and arachidonic acids (Goudoum et al., 2015).
However, the consumption of CPO can also be detrimental to human beings, as CPO contains some components which are likely to enhance numerous reactions (hydrolysis, oxidation, etc.) involved in the degradation of this product (Nwosu-Obieogu et al., 2017). Moreover, these degradation reactions can also be initiated and/or accentuated by poor transportation and storage conditions (Tagoe et al., 2012) of the product as it is generally the case among small holders. The most effective degradation process of CPO is acidification which was already mentioned by Desassis in 1957 (Ngando-Ebongue et al., 2013).

Previous studies tend to demonstrate that, there was a problem with the consumption of CPO with respect to food safety. Based on the determination of the physicochemical parameters studied by Ngando et al. (2011), CPO from small holders' extraction sites was of lesser quality was compared to that from industrial oil mills regarding to food safety. Agbaire, 2012 report on the quality assessment of palm oil sold in some major markets in Delta State, Southern Nigeria revealed that the investigated parameters where all within the SON/NIS standard, indicating that the palm oil is of good quality and there was no evidence of adulteration (SON, 2000).

This paper is aimed at studying the effect of four different processing methods and storage time on the physical characteristics of palm oil. This work will help in finding out the optimum processing technique and storage time to be employed to maintain the quality of palm oil.

\section{MATERIAL AND METHOD}

\section{Source of sample}

The palm fruits were obtained from Umuoparaozara, Olokoro, Umuahia South Local Government Area, Abia State, Nigeria and the palm oil samples used for the analysis were obtained from four different processing methods. The various processing methods for the production of the palm oil samples were employed.

\section{Process of cold extraction sample}

This process involved getting the fresh fruits, cleaning and pounding it, and then the nuts were removed and low heated to facilitate the fluidity of the oil. The pulps were hand pressed out manually. The oil was filtered and the result was clear oil. The process of heating does not involve addition of water and only low heating temperature $\left(50^{\circ} \mathrm{C}\right)$ is allowed to prevent bleaching. The flavor of the oil was strong and of fine aroma. The flow chart is shown in Figure 1.

\section{Method of hot extraction of palm oil sample}

The process involved cutting the bunch, keeping it for two 


\section{Fresh Fruits}

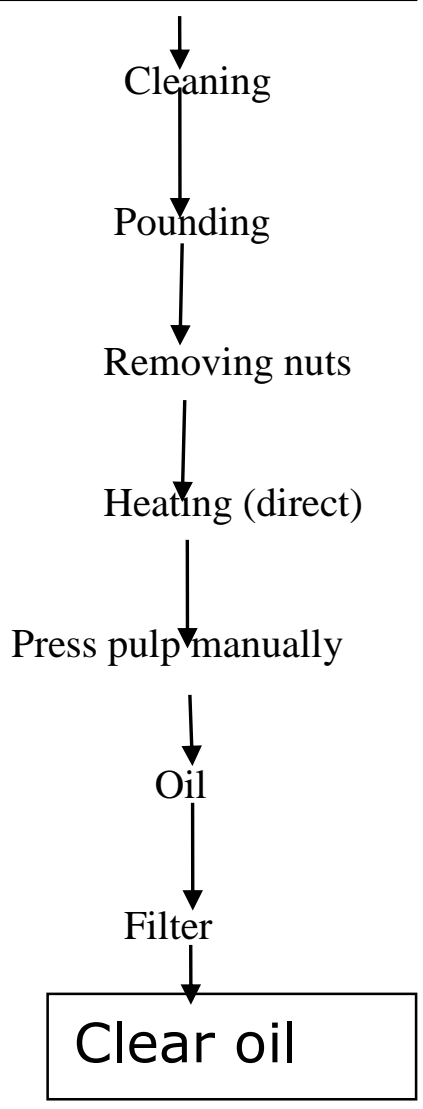

Figure 1. Flow chart for cold extraction of palm oil sample.

or three days, this was to facilitate the removal of the fruit from the bunch, after which the fruits were cleaned and heated at $100^{\circ} \mathrm{C}$ with small water until soft. The fruits were placed in a pounder and were pounded. After pounding, the nuts were separated from the pulp by sorting them out and kept in a pot and cold water was added to it which aided in scooping out the oil which floats on the surface of the water. Thereafter, the oil was heated to separate oil from water. After the nuts' removal, the pulp was placed in a bag and the oil pressed out using a locally made pressing machine. The locally made pressing machine facilitated oil extraction. The product got after pressing was mainly oil and some water. The mixture was then heated to separate oil from water. The oil floats on the surface of the water since water is of higher density. The floating oil was scooped out. The flow chart is as shown in Figure 2.

\section{Process of hot extraction of palm oil sample with red} sand

The process of hot extraction using red sand involved
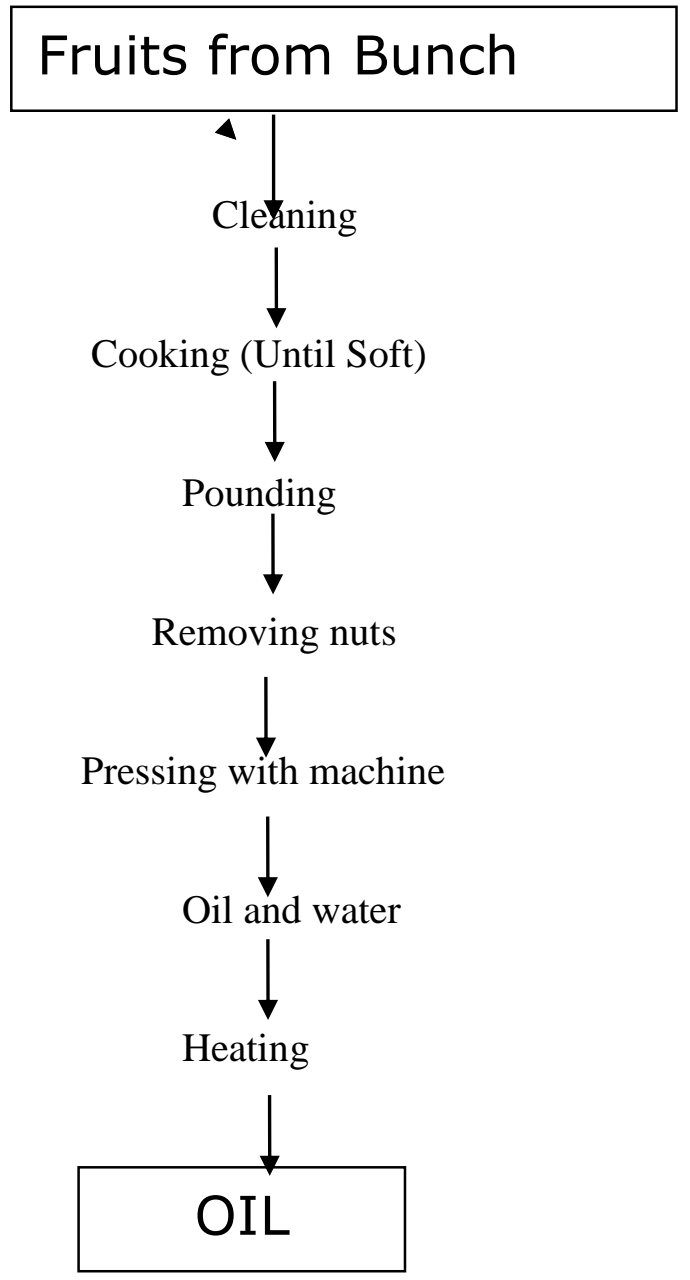

Figure 2. Flow chart for hot extraction of palm oil sample.

cutting the bunch, keeping it for two or three days to enhance removal of the fruits from the bunch, the fruits were cleaned and heated with small water until soft. The fruits were placed in pounder and red sand added, before pounding. The red sand was to add friction needed to bruise the fruits well prior to oil extraction. After pounding, the fibre was separated from the nuts. This was followed by pressing of the oil using a manual pressing machine (locally made) to extract the oil. The locally made pressing machine facilitated oil extraction. The product got after pressing was mainly oil and some water. Heating $\left(100^{\circ} \mathrm{C}\right)$ was employed to separate oil from water. The oil floated on the surface of the water because water is denser than oil. The floating oil was scooped out. The flow chart is shown in Figure 3.

\section{Mechanized processing method}

The mechanized palm oil processing adopted for the purpose of this study was got from Itaja Olokoro in 


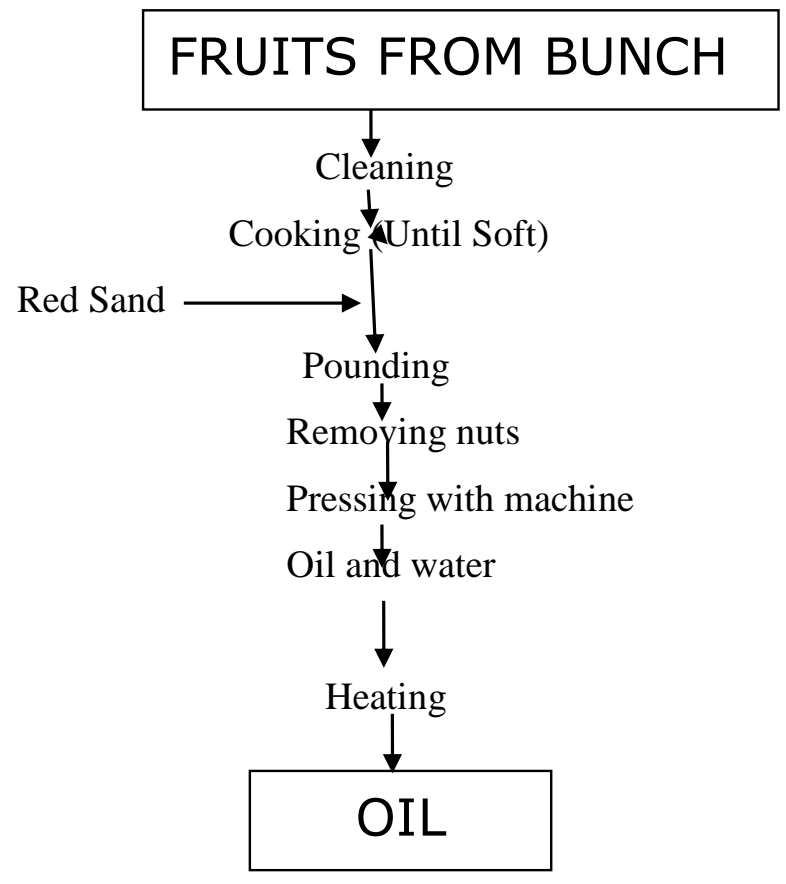

Figure 3. Flow chart for hot extraction of palm oil sample with red sand.

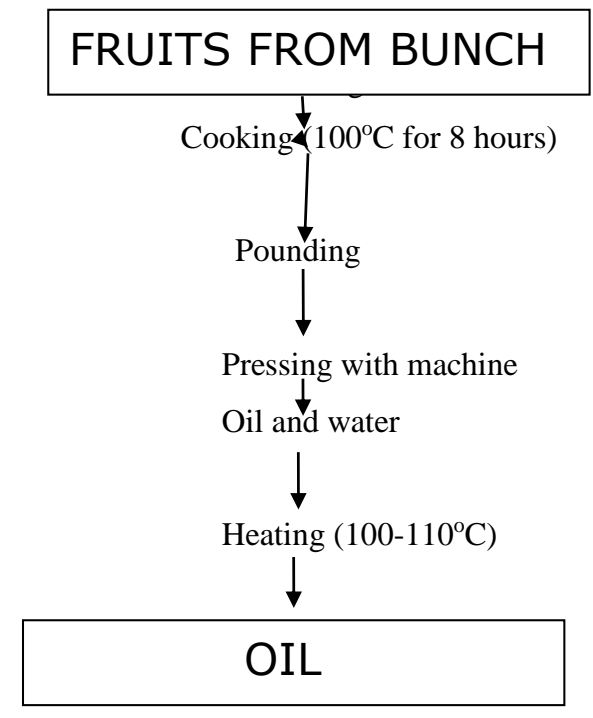

Figure 4. Flow Chart for mechanized extraction of palm oil sample.

Umuahia, Abia State, Nigeria. In this process, there is a very big pot used in boiling of the palm fruits after which it was transferred to the machine that pounds, separate the pulp from the nuts and extracts the oil. The method of palm oil processing involved the use of locally made machines in processing of the fresh fruits to detain good quality and quantity of oil (Figure 4).

\section{Analysis of physical characteristics of palm oil samples}

The physical properties of palm oil samples were determined according to Nielsen (2010). Fire points were determined according to Onwuka (2005) and (2018).

\section{Determination of moisture content}

The moisture content was determined as described by Goudoum et al. (2015). A mass of 10 grams of thoroughly mixed palm oil sample was weighed into a known mass of clean Petri dish which had been previously dried and cooled in desiccators. It was placed in the oven for four (4) hours, allowed to cool to room temperature in desiccators for 45 minutes (Bahadi et al., 2016; Salimon and Ahmed, 2012; Japir et al., 2017) and further weighed. This was repeated till a constant weight was obtained. The moisture was expressed in percentage by mass using the formula according to Goudoum et al. (2015).

$\%$ Moisture Content $=\frac{M_{b-M_{d}}}{M_{b-M}} \times 100$---------------Equation 1

Where: $M=$ Mass $(\mathrm{g})$ of Petri dish, $M_{b}=$ Mass $(\mathrm{g})$ of Petri dish + sample and $M_{d}=$ Mass $(\mathrm{g})$ of Petri dish + test sample after drying.

\section{Cloud point}

Determination of cloud point was conducted according to MPOB Test Method (2004). The oil samples (60 to $75 \mathrm{~g}$ ) were filtered through a Whatman No. 1 filter paper. The filtered oils were heated to $130^{\circ} \mathrm{C}$ for 5 minutes and about $45 \mathrm{ml}$ of the heated oil was poured into a Beatson sample bottle. The bottle and content were cooled in a water-bath that was thermostatically controlled at $5^{\circ} \mathrm{C}$ below the expected cloud point. The oils were kept stirred while cooling to prevent super-cooling and solidification of fat crystals on the side or bottom of the bottle. The bottle was removed from the bath and inspected regularly. The cloud point was taken as the temperature at which that portion of the thermometer immersed in the oil is no longer visible when viewed horizontally through the bottle and sample. Samples were run in triplicate and average values were taken (Norizzah et al., 2014).

\section{Smoke point}

The temperature at which samples give off a thin, continuous stream of bluish smoke was measured according to AOAC Method (1999). This measurement was done in triplicates.

\section{Determination of specific gravity}

Specific gravity is the ratio of the mass of a given volume 
to the mass of an equal volume of water (Singh and Heldman, 2009). The specific gravity decreases with increased temperature and decreases slightly as viscosity decreases for similar compositions (Akinola et al., 2010; Gunstone, 2011). Ten (10) $\mathrm{ml}$ of distilled water was weighed in a specific gravity bottle on weighing balance and the weight was recorded as $W_{1}$. Ten (10) $\mathrm{ml}$ of the oil sample was also weighed on the weighing balance and the weight was recorded as $W_{2}$. The determinations of the specific gravity of the palm oil samples were done in triplicates.

Specific Gravity $=\frac{W_{2}}{W_{1}}$-------------------Equation 2

\section{Determination of melting point}

The melting point was determined using AOCSCc 3-25 method (AOCS, 1989). Capillary tubes were inserted into the blended oil samples to obtain a $10 \pm 2 \mathrm{~mm}$ long column of oil sample; the capillary tubes were then sealed at one end using a Bunsen flame. The capillary tubes with the oil sample were kept in a refrigerator for three days during which the oil became solidified. With the help of a thread, the capillary tube with the sample was tie to a thermometer and inserted into a water bath at $30^{\circ} \mathrm{C}$. The temperature at which the oil began to rise up in the tube was recorded as the melting point (Goudoum et al., 2015). The determinations of the melting point of the palm oil samples were done in triplicates.

\section{Determination of refractive index}

Refractive index of oil samples was determined in triplicates at room temperature, $40^{\circ} \mathrm{C}$ and $60^{\circ} \mathrm{C}$ using Abbe refractometer as described by Akinola et al. (2010). The refractive indices $(\mathrm{RI})$ of the palm oils were measured by a refractometer at constant pressure. The TZS (2001) protocols were followed. An Abbe refractometer connected to a thermostatically controlled at $40^{\circ} \mathrm{C}$ water bath with a circulating pump was used. Two drops of each sample were placed on the lower prism. The prism was closed, tightened firmly with the screw-head and allowed to stand for 1 to 2 minutes after which the determination of RI was done. Ethanol was used for cleaning the prism of the refractometer (Ngassapa et al., 2012; Olaniyi et al., 2014).

\section{Statistical analysis}

Duplicate data obtained were subjected to statistical analysis using SPSS software of version 21. Mean values were determined and ANOVA was done as well as Fisher's Least Significant Difference (Pallant, 2004) was used to determine for the separation of the means at $(p \geq 0.05)$.

\section{RESULTS AND DISCUSSION}

\section{Specific gravity}

Table 1 showed that the storage period had no significant effect on the specific gravity of the palm oil $(p<0.05)$. The specific gravity of the freshly palm oil was 0.9045 and reduced to 0.8977 after three months storage. This could be attributed to the fact that there was no change in mass and volume of palm oil during the period under study. This is contrary to Gulla et al. $(2010,2011)$ who stated that the specific gravity of oil blends increased after 12 months storage but it is in agreement with Zaeroomali et al. (2014). Table 2 showed that the processing method has no significant effect on the specific gravity $(p \leq 0.05)$ of the palm oil. Adetola et al. (2016) reported that that the specific gravity decreased with time, such that the specific gravity was 1.09 at 21 days, it decreased to 0.91 in the transparent container and 0.90 in the opaque container. The values obtained for specific gravity of the palm oil samples are similar to 0.9003 reported by Akinyeye et al. (2011) and 0.89 to 0.92 by Koushki et al. (2015) and the standard range of 0.898 to 0.907 approved by SON (2000).

\section{Cloud point}

There was significant difference $(p \leq 0.05)$ in cloud points of the palm oil stored for 0 to 3 month(s) interval (Table 1). The cloud point increased from 21.13 to $24.13^{\circ} \mathrm{C}$. There was no significant difference between the cloud point of palm oil stored at 2 and 3 months $\left(23.60\right.$ to $\left.24.13^{\circ} \mathrm{C}\right)$ at $p<0.05$. However, the cloud point of two month stored palm oil $\left(23.60^{\circ} \mathrm{C}\right)$ was significant different from palm oil stored for 1 month $\left(22.48^{\circ} \mathrm{C}\right)$. There was also significant difference between the cloud point of freshly prepared palm oil $\left(21.13^{\circ} \mathrm{C}\right)$ cloud point and of 1 month stored palm oil $\left(22.48^{\circ} \mathrm{C}\right)$. This significantly increased cloud point $\left(21.13^{\circ} \mathrm{C}\right.$ to $24.13^{\circ} \mathrm{C}$ ) of palm oil stored for 0 to 3 month(s). This increase in cloud point could be that there was no winterization (Nielsen, 2010) done to palm oil during processing. The effect of cloud points $\left(22.38^{\circ} \mathrm{C}\right.$ to $\left.23.56^{\circ} \mathrm{C}\right)$ of palm oil significantly increased due to the processing methods (Table 2). This close range of cloud point could be attributed to no winterization application in all the processing methods. The cloud point is closely related to degree of unsaturation where the more unsaturated a sample is, the lower the cloud point will be (Khalid et al., 2011). Lai et al. (2005) reported that cloud point value for palm oil is $+11.5^{\circ} \mathrm{C}$ because of more unsaturation in the palm oil.

\section{Smoke point}

Table 1 shows that there were significant decrease $(p \leq 0.05)$ in the smoke point $\left(195.30\right.$ to $\left.186.30^{\circ} \mathrm{C}\right)$ of the 
Table1. Mean values of effect of storage time on the physical characteristics of palm oil.

\begin{tabular}{|c|c|c|c|c|c|c|c|c|}
\hline \multirow{2}{*}{$\begin{array}{l}\text { Storage Time } \\
\text { (Month) }\end{array}$} & \multicolumn{8}{|c|}{ Parameters } \\
\hline & SG & $\mathrm{CP}\left({ }^{\circ} \mathrm{C}\right)$ & $\mathrm{SP}\left({ }^{\circ} \mathrm{C}\right)$ & MP $\left({ }^{\circ} \mathrm{C}\right)$ & FLP $\left({ }^{\circ} \mathrm{C}\right)$ & $\mathrm{F}_{\mathrm{R}} \mathrm{P}\left({ }^{\circ} \mathrm{C}\right)$ & MC (\%) & RI \\
\hline 0 & $0.905 \pm 0.009^{a}$ & $21.13 \pm 0.89^{c}$ & $195.30 \pm 1.48^{a}$ & $39.54 \pm 0.56^{c}$ & $252.37 \pm 14.12^{a}$ & $314.87 \pm 2.38^{a}$ & $0.068 \pm 0.02^{b}$ & $1.45 \pm 0.02^{a}$ \\
\hline 1 & $0.906 \pm 0.004^{a}$ & $22.48 \pm 0.67^{\mathrm{b}}$ & $191.88 \pm 2.25^{b}$ & $40.63 \pm 0.65^{b}$ & $251.25 \pm 9.44^{a}$ & $311.75 \pm 2.25^{a b}$ & $0.103 \pm 0.02^{b}$ & $1.43 \pm 0.04^{b}$ \\
\hline 2 & $0.898 \pm 0.001^{\mathrm{a}}$ & $23.60 \pm 0.39^{a}$ & $189.30 \pm 4.02^{b c}$ & $41.48 \pm 0.72^{\mathrm{a}}$ & $249.62 \pm 10.56^{\mathrm{ab}}$ & $310.50 \pm 2.52^{b c}$ & $0.125 \pm 0.02^{b}$ & $1.38 \pm 0.01^{c}$ \\
\hline 3 & $0.898 \pm 0.001^{a}$ & $24.13 \pm 0.64^{\mathrm{a}}$ & $186.30 \pm 4.21^{c}$ & $41.88 \pm 0.42^{\mathrm{a}}$ & $244.62 \pm 11.54^{b}$ & $306.37 \pm 2.70^{c}$ & $0.390 \pm 0.44^{a}$ & $1.37 \pm 0.01^{\mathrm{c}}$ \\
\hline LSD & 0.0117 & 1.069 & 3.023 & 0.5711 & 6.273 & 4.311 & 0.228 & 0.0159 \\
\hline
\end{tabular}

Mean \pm Standard deviation of triplicate. Means with the same superscript within a column are not significantly different from each other ( $\mathrm{p} \leq 0.05)$.

KEY: SG = Specific Gravity; CP = Cloud Point; SP = Smoke Point; MP = Melting Point; F $\mathrm{P}=$ Flash Point; $F_{R} P=$ Fire Point; $M C=$ Moisture Content; RI = Refractive Index; LSD = Least Significant Difference.

Table2. Mean values of effect of processing methods on the physical characteristics of palm oil.

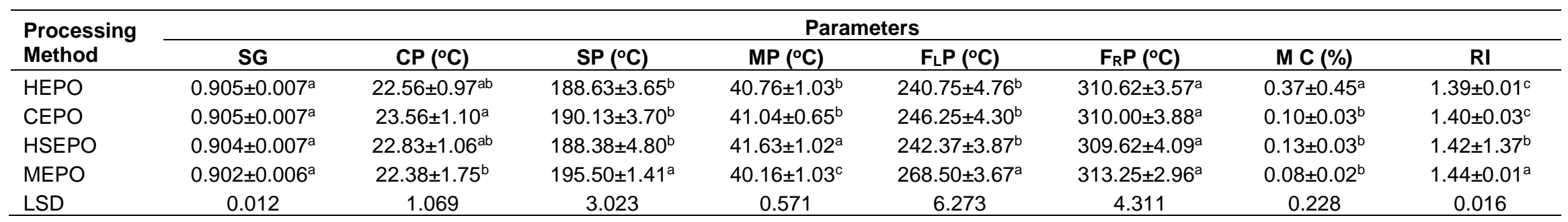

Mean \pm Standard deviation of triplicate. Means with the same superscript within a column are not significantly different from each other ( $\leq \leq 0.05$ ).

KEY: HEPO $=$ Hot Extraction Method of Palm Oil: CEPO = Cold Extraction Method of Palm Oil; HSEPO = Hot Extraction with Red Sand of Palm Oil; MEPO $=$ Mechanized Extraction Method of Palm Oils; SG = Specific Gravity; $C P=$ Cloud Point; SP $=$ Smoke Point; $M P=$ Melting Point; $F_{L} P=$ Flash Point; $F_{R} P=$ Fire Point; $M C=$ Moisture Content; RI = Refractive Index; LSD = Least Significant Difference.

palm oil stored for 0 to 3 month(s) but the results were higher than the results $\left(114.0\right.$ to $\left.116.2^{\circ} \mathrm{C}\right)$ obtained by Enyoh et al. (2017a;b). The freshly prepared palm oil had higher smoke point than other samples of 1 to 3 month(s) storage. The freshly prepared palm oil had smoke point of $195.25^{\circ} \mathrm{C}$ which was significant different from others. There was no significant difference between the palm oil stored from 1 to 2 month(s) while there was significant difference between the smoke point of palm oil stored for 1 month $\left(191.88^{\circ} \mathrm{C}\right)$ and palm oil stored for 3 months $\left(186.30^{\circ} \mathrm{C}\right)$. Moreover, there was no significant different in smoke point of palm oil stored for 2 months and 3 months. Table 2 showed that the smoke point of palm oil produced by mechanized extraction method $\left(195.5^{\circ} \mathrm{C}\right)$ was significantly higher than the smoke points of other methods: CEPO $\left(190.13^{\circ} \mathrm{C}\right)$; HEPO $\left(188.63^{\circ} \mathrm{C}\right)$; and HSEPO $\left(188.38^{\circ} \mathrm{C}\right)$. This significant difference in smoke point could be due to the presence of volatile organic materials especially free fatty acids and residual extracting solvents. Nielsen (2010) reported that frying oils and refined oils should have smoke points above $200^{\circ} \mathrm{C}$ and $300^{\circ} \mathrm{C}$ respectively.

\section{Melting point}

Table 1 shows that there was significant difference among the samples at $p \leq 0.05$. Fresh prepared palm oil had melting point $\left(39.54^{\circ} \mathrm{C}\right)$ which was 
significantly $(p \leq 0.05)$ different from palm oil stored for 1 month $\left(40.63^{\circ} \mathrm{C}\right)$. The palm oil stored for 1 month was significantly different from that stored for 2 months. There was no significant difference between palm oil for 2 and 3 months. Indeed, during storage, edible oils undergo physical and chemical changes under the influence of factors such as light, heat, trace metals and water. These changes give rise to secondary products called oxidation products. Similarly, Table 2 also showed that the melting point of palm oil produced by HSEPO $\left(41.63^{\circ} \mathrm{C}\right)$ was significantly higher than that of CEPO $\left(41.04^{\circ} \mathrm{C}\right)$ and the melting point of CEPO is statistically the same with that of HEPO $\left(40.76^{\circ} \mathrm{C}\right)$. However, the melting point of HEPO was significantly higher than that of MEPO $\left(40.16^{\circ} \mathrm{C}\right)$. The melting points obtained in this research were higher than the melting point $\left(34.2^{\circ} \mathrm{C}\right)$ obtained by Koushki et al. (2015) which are in the range of $27^{\circ} \mathrm{C}$ to $50^{\circ} \mathrm{C}$ specified by SON (2000). The factors affecting melting point of oils include double band, chain length, cis and trans structures, conjugated and unconjugated structures, the composition of fatty acids and the compounds generated in oil. This significant increase in melting point could be the presence of various components in the palm oil especially free fatty acids (Nielsen, 2010; Zaeroomali et al., 2014), and also the redistribution of the fatty acid chains within the triacylglycerol molecules (Sellami et al. 2012). According to Goudoum et al. (2015), changes at the melting point of the oils could be explained by the hydrolysis of triglycerides and the progressive oxidation observed during storage. The gradual hydrolysis of triglycerides materialized by an increase of the acid value of the oils, releases free fatty acids which are preferred substrates from oxidation.

\section{Flash point}

Table 1 shows that there was a significant $(p \leq 0.05)$ decrease in the flash point of the palm oil samples stored for 0 to 3 month(s) intervals. There was no significant difference among the freshly prepared palm oil $\left(252.37^{\circ} \mathrm{C}\right)$ and that stored for 1 to 2 month(s) and also no significant difference exists between the palm oil stored for 2 months $\left(249.62^{\circ} \mathrm{C}\right)$ and palm oil stored for 3 months $\left(244.62^{\circ} \mathrm{C}\right)$. Table 2 also illustrated that the flash point of MEPO $\left(268.50^{\circ} \mathrm{C}\right)$ was significantly $(p \leq 0.05)$ higher than other processing methods: CEPO $\left(246.25^{\circ} \mathrm{C}\right)$; HSEPO $\left(242.37^{\circ} \mathrm{C}\right)$; and HEPO $\left(240.75^{\circ} \mathrm{C}\right)$. Though, there was variation in the flash points of HSEPO, CEPO and HEPO but they were statistically the same $(p \geq 0.05)$. These variations in the flash points could be attributed to the presence of volatile organic materials in palm oil especially free fatty acids and residual extraction solvents (Nielsen, 2010).

\section{Fire point}

Table 1 illustrated that the fire points of palm oil stored for
0 to 3 month(s) decreased significantly (314.87 to $306.37^{\circ} \mathrm{C}$ ). Freshly prepared palm oil was not significantly different from the palm oil stored for 1 month; two months stored palm oil had a fire point of $310.50^{\circ} \mathrm{C}$ which was not significantly different from the palm oil stored for 1 month $\left(311.75^{\circ} \mathrm{C}\right)$ but significantly different $(p \leq 0.05)$ from the freshly prepared palm oil. However, palm oil stored for 3 months had a fire point $\left(306.37^{\circ} \mathrm{C}\right)$ which was not significantly different from the palm oil stored for 2 months but significantly different from freshly prepared palm oil and that stored for 1 month. Table 2 showed that there was no significant difference $(p \leq 0.05)$ in the fire points of the processing methods: MEPO $\left(313.25^{\circ} \mathrm{C}\right)$; HEPO $\left(310.62^{\circ} \mathrm{C}\right)$; CEPO $\left(310.00^{\circ} \mathrm{C}\right)$ and HSEPO $\left(309.62^{\circ} \mathrm{C}\right)$. This could be due to the presence of the volatile organic materials in the palm oil samples (Nielsen, 2010).

\section{Moisture content (\%)}

Table 1 showed that there was significant increase $(p \leq 0.05)$ in moisture contents $(0.068$ to $0.39 \%)$ of the palm oil stored for 0 to 3 month(s). The freshly prepared palm oil had moisture content of $0.068 \%$ which was not significantly different from the samples of palm oil stored for 1 and 2 month(s) (0.103 and $0.125 \%$ respectively). However, palm oil stored for 3 months had $0.39 \%$ moisture content which was significantly different from other samples. Also, Table 2 showed that there were significant variations in the moisture contents $(0.08$ to $0.37 \%)$ of the palm oil samples due to the processing methods and some are not far from the recommended value of $0.2 \%$ for fresh oil specified by SON (2000). Similar trends were observed by Zu et al. (2012) and Koushki et al. (2015) that storage time and processing technique could cause significant effects on moisture content of the crude palm oil. This significant increase in moisture content could cause hydrolytic rancidity of palm oil (Nielsen, 2010).

\section{Refractive index}

Table 1 showed significant decrease in refractive index of palm oil stored for 0 to 3 months(s) at ( $p \leq 0.05)$. The freshly prepared palm oil had refractive index (1.45) which was significantly different from the palm oil stored for 2 and 3 months. However, there was no significant difference between the palm oil stored for 2 months (1.38) and 3 months (1.37). Table 2 illustrated that there were significant effects in refractive index of palm oil caused by processing methods: HEPO (1.39); CEPO (1.40); HSEPO (1.42) and MEPO (1.44). Ngassapa et al. (2012) reported that the variations in refractive index of palm oil produced by the different processing methods could be attributed to unsaturation. These values obtained are lower than the 1.4600 obtained by Akinyeye et al. (2011) and Koushki et al. (2015). This significant decrease $(p \leq 0.05)$ in refractive index of palm oil stored for 0 to 3 month(s) could be 
attributed to the factors such as free fatty acids, oxidation and heating of the palm oil (Akinola et al., 2010; Nielson, 2010).

\section{Conclusion}

The results of the effects of processing methods and storage time on the physical characteristics of palm oil were determined. Storage time caused no significant effect on the specific gravities of the palm oil samples while it caused significant increase in the following physical characteristics of the palm oil samples: cloud point, melting point and moisture content. However, storage time caused significant decrease in the following physical characteristics of palm oil samples: smoke point, flash point, fire point and refractive index. The processing methods had no significant effect on specific gravity and fire point whereas it caused significant variations in cloud point, smoke point, melting point, flash point, moisture content and refractive index. Mechanized extraction method of palm oil was observed as the best method because its palm oil had the least specific gravity (0.902), least cloud point $\left(22.38^{\circ} \mathrm{C}\right)$, highest smoke point $\left(195.50^{\circ} \mathrm{C}\right)$, least melting point $\left(40.16^{\circ} \mathrm{C}\right)$, highest flash point $\left(218.50^{\circ} \mathrm{C}\right)$, highest fire point $\left(313.25^{\circ} \mathrm{C}\right)$, least moisture content $(0.08 \%)$ and highest refractive index (1.44).

\section{Recommendation}

Effort should be made in proper packaging of palm oil as well as the reduction of the physical parameter which might cause an adverse effect on the quality of palm. It is recommendable to study the effect of processing methods and storage time on chemical properties of palm oil.

\section{CONFLICT OF INTEREST}

The authors declare that they have no conflict of interest.

\section{REFERENCES}

Adetola, O. A., Alabi, O. O., \& Abdulrauf, I. A. (2016). Investigating storage duration and packaging materials on quality of fresh palm oil. FUTA Journal of Research in Sciences, 12(2), 252-259.

Agbaire, P. O. (2012). Quality Assessment of palm oil sold in some major markets in Delta State, Southern Nigeria. Africa Journal of Food Science and Technology, 3(9), 223-226.

Akinola, F. F., Oguntibeju, O. O., Adisa, A. W., \& O. S. Owojuyigbe, O. S. (2010). Physico-chemical Properties of Palm Oil from Different Palm Oil Local Factories in Nigeria. Journal of Food, Agriculture \& Environment, 8(3\&4), 264-269.

Akinyeye, R. O., Adeyeye, E. I., Fasakina, O., \& Agboola, A. (2011). Physico-chemical properties and anti-nutritional factors of palm fruit products (Elaeis guineensis Jacq.) from Ekiti State Nigeria. Electronic Journal of Environmental, Agricultural and Food Chemistry, 10(5), 2190-2198.

AOCS (1989). The Determination of Melting Point in Open Capillary Tubes (Slip Point) for Palm Oil Products. In: AOCSCc 3-25. AOCS Press, Champaign, IL.

AOAC (1999). Official Methods of Analysis. 16th Edition. Washington: Association of Official Analytical Chemists Inc.

Bahadi, M. A., Japir, A. W., Salih, N., \& Salimon, J. (2016). Free fatty acids separation from Malaysian high free fatty acid crude palm oil using molecular distillation. Malaysian Journal of Analytical Sciences, 20(5), 1042-1051.

Barku-Atsu, V. Y., Nyarko, H. D., \& Dordunu, P. (2012). Studies on the physicochemical characteristics, microbial load and storage stability of oil from Indian Almond Nut (Terminalia catappa I.). Food Science and Quality Management, 8(1), 917.

Enyoh, E. C., Enyoh, C. E., \& Amaobi, C. E. (2017a). Quality assessment of palm oil from different palm oil local factories in Imo State, Nigeria. World Scientific News (WSN), 88(2), 152167.

Enyoh, C. E., Ihionu, E. A., Wirnkor, V. A., \& Ebosie, P. N. (2017b). Physicochemical parameter of palm oil and soil from Ihube Community, Okigwe, Imo State Nigeria. International Letters of Natural Sciences, 62, 35-43.

FAO (2000). World Agriculture towards 2015/2030: Summary Report. Food and Agricultural Organization of United Nations publications, Rome.

FAO/WHO (2013). Alimentarius C. Standard for Named Vegetable Oils -Codex Stan 210-1999. p. 16.

Goudoum, A., Makambeu, N. A., Abdou, B. A., \& Mbofung, C. M. (2015). Some physicochemical characteristics and storage stability of crude palm oils (Elaeis guineensis Jacq). American Journal of Food Science and Technology, 3(4), 97-102.

Gulla, S., Waghray, K., \& Reddy, U. (2010) Blending of Oils: Does it improve the quality and storage stability, an experimental approach on soybean and palm oil based blends. American Journal of Food Technology, 5,182-194.

Gulla, S., \& Waghray, K. (2011). Effect of storage on physicochemical characteristics and fatty acid composition of selected oil blends. Journal of Life Sciences, 3(1), 35-46.

Gunstone, F. (2011). Vegetable Oils in Food Technology: Composition, Properties and Uses. John Wiley \& Sons, Oxford.

Ihekoronye, A. I., \& Ngoddy, P. O. (1985). Integrated Food Science and Technology for the Tropics. Macmillan Publishers, London. Pp. 251-253.

Izah, S. C., \& Ohimain, E. I. (2013). Microbiological Quality of Crude Palm Oil Produced by Smallholder Processors in the Niger Delta, Nigeria. Journal of Microbiology and Biotechnology Research, 3(2), 30-36.

Japir, A. A-W., Salimon, J., Derawi, D., Bahadi, M., Al-Shuja'a, S., \& Yusop, M. R. (2017). Physicochemical characteristics of high free fatty acid crude palm oil. Oilseeds and Fats, Crops and Lipids, 24(5), D506.

Khalid, K., Mushaireen, M., Kamaruzaman, J., \& Rahman, A. (2011). Lowering of Palm Oil Cloud Point by Enzymatic Acidolysis. World Applied Science Journal, 12, 28-31.

Koushki, M., Nahidi, M., \& Cheraghali, F. (2015). Physicochemical properties, fatty acid profile and nutrition in palm oil. Journal of Paramedical Sciences (JPS) Summer, 6(3), 117134.

Lai, T. C., Nazaruddin, R., Ooi, T. L., Mamot, S., \& Zalifah, K. (2005). Strategies for decreasing the pour point and cloud point 
of palm oil products. European Journal of Lipid Science Technology, 107, 505-512.

MPOB Test Method. (2004). Methods of test for palm oil and palm oil products, Malaysia: Malaysian Palm Oil Board.

Ngando-Ebongue, G. F., Dhouib, R., Carriere, F., Amvam-Zollo, P. H., \& Arondel, V. (2006). Assaying Lipase Activity from Oil Palm Fruit (Elaeisguineensis Jacq.) Mesocarp. Plant Physiol. Biochem., 44, 611-617.

Ngando-Ebongue, G. F., Mpondo-Mpondo, E. A., Dikotto, E. E. L., \& Koona, P. (2011). Assessment of the quality of crude palm oil from smallholders in Cameroon. Journal of Stored Products and Postharvest Research, 2(3), 52-58.

Ngando-Ebongue, G. F., Mpondo-Mpondo, E. A., \& Ewane, M. A. (2013). Some quality parameters of crude palm oil from major markets of Douala, Cameroon. African Journal of Food Science, 7(12), 473-478.

Ngassapa, F. N., Nyandoro, S. S., \& Mwaisaka, T. R. (2012). Effects of temperature in the physico-chemical properties of traditionally processed vegetable oils and their blends. Tanzania Journal of Science, 38(3),166-176.

Nielsen, S. S. (2010). Food Analysis 4th Edn. Springer Science and Business Media, New York. Pp. 241-259.

Norizzah, A. R., Norsyamimi, M., Zaliha, O., Nur Azimah, K., \& Siti Hazirah, M. F. (2014). Physicochemical properties of palm oil and palm kernel oil blend fractions after interesterification. International Food Research Journal, 22(4), 1390-1395.

Nwosu-Obieogu, K., Aguele, F., Chiemenem, L., \& Adekunle, K. (2017). Analysis on the Physicochemical Properties of Palm Oil within Isiala Ngwa Local Government Area of Abia State,Nigeria. International Journal of Bioorganic Chemistry, 2(4), 159-162.

Ohimain, E. I.; Oyedeji, A. A., \& Izah, S. C. (2012). Employment Effects of Smallholder Oil Palm Processing Plants in Elele, Rivers State, Nigeria. Int. J. Appl. Res. Technol. 1(6), 83-93.

Ohimain, E. I., Izah, S. C., Abah S. O. (2013). Air quality impacts of smallholder oil palm processing in Nigeria. J. Environ. Protection, 4, 83-98.

Okechalu, J. N., Dashen, M. M., Lar, P. M., Okechalu, B., \& Gushop, T. (2011). Microbiological quality and chemical characteristics of palm oil sold within Jos Metropolis, Plateau State, Nigeria. Journal of Microbiology and Biotechnology Research, 1(2), 107-112.

Olaniyi, A. P., Babalola, O. O., \& Oyediran, A. M. (2014). Physicochemical properties of palm kernel oil. Current Research Journal of Biological Sciences, 6(5), 205-207.
Onwuka, G. I. (2005). Food Analysis and Instrumentation: Theory and Practice. Naphtali Prints, Surulere, Lagos. Pp. 63-75.

Onwuka, G. I. (2018). Food Analysis and Instrumentation: Theory and Practice. 2nd Edn. Naphtali Prints, Lagos. Pp. 179-228.

Pallant, J. (2004). SPSS Survival Manual. Open University Press, Berkshire.

Salimon, J., \& Ahmed, W. A. (2012). Physicochemical Characteristics of Tropical Jatrophacurcas Seed Oil. Sains Malaysiana 41: 313-317.

Sellami, M., Ghamgui, H., Frikha, F., Gargouri, Y., \& Miled, N. (2012). Enzymatic transesterification of palm stearin and olein blends to produce zero-trans margarine fat. $B M C$ Biotechnology 12, 48.

Singh, R. P., \& Heldman, D. R. (2010). Introduction to Food Engineering 4th Edn. Academic Press, New York. Pp 24-25.

SON (2000). Standards for Edible Refined Palm Oil and its Processed Forms. Standards Organisation of Nigeria. Pp. 2-5.

Tagoe, S. M. A., Dickinson, M. J., \& Apetorgbor, M. M. (2012). Factors Influencing quality of palm oil produced at cottage industry level in Ghana. International Food Research Journal19(1): 271-278.

TZS (2001). Tanzania standards, sampling and test methods for palm oil and palm oil products. Tanzania Bureau of Standards 561.

Umoh, I. B. (1998). Commonly used fruits in Nigeria, Benin, post-harvest. Res. Unit Dept. Biochem. Univ. Benin, 1, 84130.

Zaeroomali, M., Maghsoudlou, Y., \& Aryaey, P. (2014). Investigation on physicochemical properties of table margarine during storage time in ambient temperature. European Journal of Experiment Biology, 4(3), 185-190.

Zu, K. S. A.; Adjei-Nsiah, S. \& Bani, R. J. (2012). Effect of processing equipment and duration of storage of palm fruits on palm oil yield and quality in the Kwaebibrem District, Ghana. Agricultural Research and Reviews, 1(1),18-25. 